\title{
UJI ANTITOKSOPLASMA EKSTRAK KASAR ALKALOID DAUN PULAI (Alstonia scholaris, (L.) R. BR) TERHADAP MENCIT (Mus musculus) BALB/C YANG TERINFEKSI Toxoplasma Gondii STRAIN RH
}

\author{
Ali Abraham, Begum Fauziyah, A.Ghanaim Fasya, Tri Kustono Adi \\ Jurusan Kimia, Fakultas Sains dan Teknologi, UIN Maulana Malik Ibrahim Malang
}

\begin{abstract}
Pulai (Alstonia scholaris, L.R.Br) is a plant with whole part, especially the leaf, contains many compounds of alkaloid. The compounds has been widely used as drug. This research was aimed to know the effectiveness of the alkaloid crude extract of Pulai's leaf in prolonging lifespan of mice infected by Toxoplasma gondii.

The alkaloid crude exctract was yielded through maseration and acid-base extraction using ethanol solvent. The antitoxoplasma assay was performed using male mice Balb/C with dose variations of $25 \mathrm{mg} / \mathrm{Kg}, 50$ $\mathrm{mg} / \mathrm{Kg}$ and $75 \mathrm{mg} / \mathrm{Kg}$ of mice bodyweight (bw). The data was also supported by observation of the amount of intraperitoneal takizoit in 8 days period of treatment. The identification and separation of the extracted alkaloids was applied using phytochemical tests and Tin Layer Chromatography (TLC).

The result showed that the alkaloid crude extract was succesfully generated with $0.37 \%$ yield. Result of research shows of alkaloid content of ethanol condensed extract equal to 0,368\% and phytochemical test results showed positive extract contains alkaloids. All dose variation of the crude extract had succesfully prolonged the lifespan of the infected mice during 8 days of treatment. The amount of takizoit intraperitoneal was counted as $7.375 \times 10^{5}$. The separation of the crude extract by TLC using etil asetat : methanol : water $(6: 4: 2)$ eluen generated 6 spots.
\end{abstract}

Key word: antitoxsoplasma, leaf Alstonia scholaris, L.R.Br, taxoplasma gondii.

\begin{abstract}
ABSTRAK
Tumbuhan pulai (Alstonia scholaris, L.R.Br) merupakan salah satu tumbuhan yang dimanfaatkan sebagai obat. Hampir seluruh bagian dari tumbuhan pulai mengandung senyawa alkaloid. Ekstraksi daun pulai bertujuan unutk mengambil senyawa alkaloid yang telah diketahui sebagai antitoksoplasma. Penelitian ini bertujuan untuk mengetahui efektivitas dan dosis terbaik dari ekstrak alkaloid terhadap daya hidup mencit yang terinfeksi parasit serta mereduksi Toxoplasma gondii yang nantinya berpotensi sebagai obat antitoksoplasma.

Ekstraksi dilakukan secara maserasi dan ekstraksi asam basa untuk pengambilan senyawa alkaloid dalam ekstrak etanol. Hasil ekstrak dilakukan Uji antitoksoplasma menggunakan mencit Balb/C jantan dengan variasi dosis yaitu $25 \mathrm{mg} / \mathrm{Kg} \mathrm{BB}, 50 \mathrm{mg} / \mathrm{Kg}$ BB dan $75 \mathrm{mg} / \mathrm{Kg}$ BB mencit dengan melihat parameter daya hidup mencit yang didukung dengan jumlah takizoit intraperitoneal selama masa terapi 8 hari. Ekstrak kasar alkaloid selanjutnya di uji fitokimia serta diidentifikasi dengan KLT.

Hasil penelitian menunjukan kadar alkaloid dari ekstrak etanol sebesar 0,37 \% dan hasil uji fitokimia menunjukan ekstrak positif mengandung alkaloid. Ekstrak kasar alkaloid baik pada dosis $25 \mathrm{mg} / \mathrm{Kg} \mathrm{BB}, 50$ $\mathrm{mg} / \mathrm{Kg} \mathrm{BB}$ dan $75 \mathrm{mg} / \mathrm{Kg}$ BB dapat memperpanjang daya hidup mencit hingga hari terapi ke-8. Dosis $25 \mathrm{mg} / \mathrm{Kg}$ $\mathrm{BB}$ memberikan daya hidup dengan sisa mencit 3 ekor dengan didukung jumlah takizoit intraperitoneal sebesar $737,5 \times 10^{3}$. Ekstrak kasar alkaloid diidentifikasi dengan menggunakan kromatografi lapis tipis (KLT) dengan eluen etil asetat : metanol : air $(6: 4: 2)$ yang menghasilkan 6 noda .
\end{abstract}

Kata Kunci: antitoksoplasma, Alstonia scholaris, L.R.Br, toxoplasma gondii

\section{PENDAHULUAN}

Toksoplasmosis merupakan salah satu penyakit yang menjadi masalah serius di berbagai belahan dunia. Toksoplasmosis adalah penyakit zoonis yang disebabkan oleh parasit Toxoplasma gondii yang merupakan protozoa golongan koksidia yang menyerang hewan dan manusia (Iskandar dkk., 2006). Infeksi Toxoplasma gondii akut yang menginfeksi wanita hamil akan mengakibatkan toksoplasmosis kongenital pada bayi, seperti lahir dengan 
kecacatan, hingga kematian pada janin yang mengakibatkan keguguran (Dubey and Weiss, 2009). Kasus toksoplasmosis pada manusia mengalami peningkatan di setiap tahunnya. Prevalensi toksoplasmosis pada manusia di Indonesia sekitar 2-63\% (Susanto dkk., 2002) dan mengalami peningkatan menjadi 43-88 \% pada tahun 2006 (Subekti dan Arrasyid, 2006). Salah satu pengobatan bagi pasien yang terjangkit kasus toksoplasmosis ibu hamil dengan pemberian obat sintesis pirimetamin yang menjadi pilihan utama dalam pengobatan toksoplasmosis. Namun pemberian pirimetamine memberikan efek samping bagi penderita karena dianggap bersifat teratogenik. Mengenai efek samping bahaya obat sintesis seperti pirimetamine telah dibuktikan oleh Kumolosasi dkk., (2004), yaitu pemberian obat pembanding pirimetamine dan sulfadoksin dengan dosis terapi $6,75 \mathrm{mg} / \mathrm{Kg}$ bb dan $235 \mathrm{mg} / \mathrm{Kg}$ bb menyebabkan keguguran pada $100 \%$ induk tikus, sedangkan seperempat dosis terapi tersebut tidak menyebabkan keguguran, tetapi menyebabkan hidrosefalus ringan pada 30,4 \% janin. Berdasarkan paparan mengenai efek samping serta bahaya dari obat sintetis di atas maka perlu dikembangkan upaya penelitian dan pencarian obat-obatan alami atau herbal dari tumbuhan sebagai pengganti obat sintesis. Masyarakat dahulu hingga sekarang meggunakan obat tradisional sebagai warisan budaya masyarakat terdahulu. Hal ini didorong pula oleh keanekargaman hayati di Indonesia yang pemanfaatannya oleh masyarakat terdahulu dengan mengkaitkan konsep sakit, sehat dan macam keanekaragaman tumbuhan yang telah terbentuk dari proses sosialisasi yang secara turun temurun dipercaya kebenarannya untuk digunakan sebagai obat tradisional (Mulyati dkk., 2006).

Hal ini dapat dilakukan pengkajian penelitian dalam bidang pengobatan alternatif yang berasal dari berbagai macam tumbuh-tumbuhan yang selama ini berkembang di masyarakat. Indonesia merupakan negara tropis yang kaya sumberdaya hayati. Hampir \pm 30.000 ribu spesies tanaman tumbuh di Indonesia, \pm 7000 diantaranya berkhasiat sebagai tanaman obat (Supriadi, 2001). Salah satu tumbuhan yang ada di Indonesia yang dimanfaatkan sebagai tumbuhan obat adalah tumbuhan pulai. Hampir semua bagian dari tumbuhan yang dapat dimanfaatkan sebagai obat adalah bagian daun, batang, akar, rimpang, bunga, buah dan bijinya (Savitri, 2008). Kandungan yang paling dominan pada beberapa bagian tumbuhan pulai adalah alkaloid (Kulsum dan Gusmailina, 2003). Hampir keseluruhan hasil penelitian dari tumbuhan pulai baik pada daun, akar dan kulit batangnya terdapat alkaloid. Sehingga dapat diduga bahwa senyawaan yang berpotensi sebagai antitoksoplasma berasal dari golongan alkaloid. Penelitian mengenai golongan senyawa alkaloid yang berpotensi sebagai antitoksoplasma telah dibuktikan oleh Lee dkk., (2012) yang menyatakan alkaloid pada ekstrak metanol kasar jambu biji (Psidium guajava L.) dan brotowali (Tinospora crispa) aktif sebagai antitoksoplasma. Hal ini juga telah dibuktikan oleh Ronize dkk, (2012) alkaloid turunan naftoquinon dan liriodenine dapat menghambat aktivitas replikasi dari Toxoplasma gondii dengan nilai $\mathrm{IC}_{50}$ yang diperoleh adalah 0,32 dan 0,07 $\mu \mathrm{M}$ (yaitu, 0,1 dan 0,02 mg / mL).

Ekstrak kasar alkaloid yang diperoleh akan dilakukan uji antitoksoplasma terhadap mencit Balb/C yang terinfeksi Toxoplasma gondii serta di uji fitokimia dengan menggunakan uji reagen dan kromatografi lapis tipis untuk mengetahui dugaan kandungan senyawaan alkaloid yang ada dan berpotensi sebagai antitoksoplasma. Hasil penelitian ini diharapkan dapat mengetahui efektivitas ekstrak kasar alkaloid dari daun pulai sebagai antitoksoplasma.

\section{METODOLOGI PENELITIAN Bahan}

Bahan utama yang digunakan dalam penelitian ini adalah bagian tanaman yakni 
daun pulai (Alstonia scholaris (L) R. Br). Bahan-bahan kimia yang digunakan dalam penelitian ini antara lain: pelarut etanol p.a, etil asetat p.a, $\mathrm{H}_{2} \mathrm{SO}_{4} 2 \%$ amonium hidroksida $\left(\mathrm{NH}_{4} \mathrm{OH} 25 \%\right)$, kloroform p.a, aseton p.a, metanol p.a, n-heksana p.a,. Bahan lain yang digunakan adalah akuades, reagen mayer, reagen dragendroff, $\mathrm{HCl}$ (asam klorida) $1 \%$ dan gas $\mathrm{N}_{2}, \mathrm{NaCl}$ fisiologis $0,9 \%$, spiramicin, ekstrak daun pulai (Alstonia scholaris (L) R. Br), mencit jantan galur Balb/C CMC-Na (Sodium Carboxyl Methyl Cellulose) dan parasit Toxoplasma gondii galur RH.

\section{Rancangan Penelitian}

Penelitian ini dilakukan melalui pengujian eksperimental di laboratorium. Sampel daun pulai diambil, dibersihkan dari debu dan kotoran, dicuci, dikeringanginkan, ditumbuk kasar, kemudian ditentukan kadar airnya. Selanjutnya daun pulai dihaluskan dengan blender lalu diayak menggunakan ayakan dengan rentang 20 mesh hingga diperoleh serbuk yang halus (berukuran 20 mesh), kemudian ditentukan kadar airnya kembali hingga kurang dari $10 \%$. Sejumlah serbuk sampel masing-masing diekstraksi maserasi dengan mengunakan pelarut etanol (1:10) sampai diperoleh filtrat yang pucat.

Filtrat yang diperoleh dipekatkan menggunakan rotary evaporator vakum pada suhu $40{ }^{\circ} \mathrm{C}$ dan dialiri gas $\mathrm{N}_{2}$. Ekstrak kental yang diperoleh kemudian dilanjutkan dengan fraksinasi alkaloid sebelum di fraksinasi ekstrak etanol $95 \%$ di lakukan pengujian fitokimia untuk mengetahui golongan senyawa alkaloid. Hasil Fraksi alkaloid selanjutnya di gunakan untuk uji antitoksoplasma untuk mengetahui daya hidup mencit selama terinfeksi takizoit Toxoplasma gondii dengan dosis terapi yang diberikan yaitu dosis $25 \mathrm{mg} / \mathrm{Kg} \mathrm{BB}$, $50 \mathrm{mg} / \mathrm{Kg}$ BB dan $75 \mathrm{mg} / \mathrm{Kg}$ BB. Selanjutnya diuji fitokimia kedua dengan menggunkan reagen dan dilanjutkan identifikasi senyawa alkaloid dengan menggunakan kromatografi lapis tipis (KLT).

\section{Analisis Kadar Air}

Tahap pertama yang dilakukan untuk menganalisis kadar air adalah mengeringkan cawan porselen dalam oven pada suhu $105{ }^{\circ} \mathrm{C}$ selama 1 jam. Cawan tersebut diletakkan ke dalam desikator (kurang lebih 15 menit) dan dibiarkan sampai dingin kemudian ditimbang. Cawan tersebut ditimbang kembali hingga beratnya konstan, sebanyak 5 gram sampel daun pulai (masing-masing basah dan kering) dimasukkan ke dalam cawan tersebut, kemudian dikeringkan dengan oven pada suhu $105{ }^{\circ} \mathrm{C}$ selama 5 jam atau hingga beratnya konstan.

Setelah selesai proses kemudian cawan tersebut dimasukkan ke dalam desikator dan dibiarkan sampai dingin dan selanjutnya ditimbang kembali. Uji kadar air masing-masing dilakukan pada sampel basah dan sampel kering. Perhitungan kadar air :

$$
\text { \% Kadar air }=\frac{B-C}{B-A} \times 100 \% \text {.....(3.1) }
$$

Keterangan:

$\mathrm{A}=$ Berat cawan kosong (gram)

$\mathrm{B}=$ Berat cawan yang diisi dengan sampel (gram)

$\mathrm{C}=$ Berat cawan dengan sampel yang sudah dikeringkan (gram)

\section{Ekstraksi Alkaloid Daun Pulai}

Serbuk daun pulai ditimbang sebanyak 100 gram dan perlakuan dibagi menjadi dua masing-masing 50 gram untuk proses maserasi. Kemudian diekstraksi secara maserasi masing-masing menggunakan pelarut etanol (1:10) selama 24 jam. Pengadukannya dibantu dengan shaker selama 3 jam, kemudian disaring dan ampas yang diperoleh dimaserasi kembali dengan pelarut etanol, dengan perlakuan yang sama sampai diperoleh filtra tidak berwarna.

Selanjutnya disaring sampai diperoleh residu (ampas) dan filtrat, kemudian residu dibuang, ekstrak etanol yang diperoleh dipekatkan dengan rotary evaporator vakum dan di aliri gas $\mathrm{N}_{2}$. Ekstrak yang didapat dilarutkan kembali dalam $\mathrm{H}_{2} \mathrm{SO}_{4} 2 \%$ kemudian ditambahkan 
dietil eter untuk menghilangkan lemak. Selanjutnya fraksi dietil eter dibuang, dan fraksi air dibasakan dengan $\mathrm{NH}_{4} \mathrm{OH} 25 \%$ sampai pH 9-10 dan diekstraksi dengan kloroform sampai tidak berwarna. ekstrak pekat yang diperoleh ditimbang dan dihitung rendemennya.

\section{Uji Antitoksoplasma}

Penelitian ini menggunakan hewan mencit (Mus musculus) galur Balb/C jenis betina yang berumur 8-10 minggu dengan berat badan rata-rata 16-20 gram/ekor. Sebelum perlakuan, mencit dipelihara dalam kandang yang diberi alas serbuk kayu dan anyaman kawat sebagai penutup. Pemberian makan dan minum dilakukan setiap hari secara ad libitum. Penelitian dilakukan dengan 5 kelompok perlakuan. Dengan masing-masing kelompok menggunakan 6 ekor hewan uji. Adapun 5 kelompok tersebut yaitu terdiri dari kelompok kontrol positif (kontrol obat spiramicin + infeksi), kelompok kontrol negative (infeksi $+\mathrm{CMCNa} 1 \%$ ), dan kelompok perlakuan ekstrak dengan masing-masing dosis yaitu $25 \mathrm{mg} / \mathrm{Kg} \mathrm{BB}$, $50 \mathrm{mg} / \mathrm{Kg} \quad \mathrm{BB}$ dan $75 \mathrm{mg} / \mathrm{Kg} \quad \mathrm{BB}$. Pengobatan dilakukan sejak hari ke-1, sampai ke-8. Proses pengamatan daya hidup mencit diamati setiap hari dan jumlah takizoit diamati pada hari ke-5.

\section{Perhitungan Jumlah Takizoit Intraperitoneal}

Perhitungan jumlah takizoit dilakukan berdasarkan kontrol negatif yang diamati setiap hari sekali dengan mengambil satu mencit sebagai sampel. Perhitungan dilakukan dihari ke-5 dengan cara mengorbankan masing-masing mencit per-kelompok perlakuan. Kemudian cairan peritoneum atau intraperitoneal kemudian ditampung di tabung ependroff. Larutan diambil dengan mikropipet dan hitung jumlah takizoit dengan alat Hemisitometer.

$100 \mu \mathrm{L}, \quad$ kemudian larutan diinkubasikan selama 90 menit. Nilai absorbansi diukur pada panjang gelombang $655 \mathrm{~nm}$ menggunakan spektrofotometri Bio-Rad Model 680. Sampel diuji sebanyak 2 kali ulangan.
Uji Alkaloid (Harbone, 1987; Saxena dkk., 2012)

Sebanyak 0,5 gr ekstrak ditambahkan $5 \mathrm{ml} \mathrm{HCl} 1 \%$ kemudian disaring. Filtrat yang diperoleh dibagi menjadi 2 dimasukkan dalam tabung reaksi. Tabung reaksi I ditambahkan 2-3 tetes reagen Dragendorff, sedangkan tabung reaksi II ditambahkan 2-3 tetes pereaksi Mayer. Jika pada tabung I terbentuk endapan merah, jingga dan pada tabung II terbentuk endapan putih atau kekuningkuningan maka ekstrak menunjukkan adanya alkaloid.

\section{Identifikasi Senyawa Alkaloid dengan Kromatografi Lapis Tipis}

Uji senyawa aktif alkaloid dilakukan dengan KLT dengan menggunakan eluen Kloroform : Aseton (1:3) dengan penyemprot Dragendorf menghasilkan 5 noda (Diah, 2012). Etil Asetat : Etanol : nHeksan (2:1:30) dengan penyemprot Dragendorf menghasilkan 5 noda (Kusrini, 2013). Kloroform : Etanol (9:1) dengan penyemprot Dragendorf menghasilkan 4 noda (Ekasari dkk., 2005).

Etanol : Metanol : Air (6:4:2) dengan penyemprot Dragendorf menghasilkan 6 noda (Marliana, 2007). Aseton : Metanol (9:1) dengan penyemprot Dragendorf menghasilkan 5 noda (Lusiana, 2009).

\section{Analisi Data}

Data yang diperoleh dibuat dalam bentuk tabel dan grafik, kemudian dideskripsikan hasilnya. Adapun data yang diperoleh $\%$ daya hidup dan Jumlah takizoit intraperitoneal terhadap ekstrak kasar alkaloid yang diberikan.

\section{HASIL DAN PEMBAHASAN Analisis Kadar Air}

Pada penelitian ini dilakukan uji analisis kadar air dari sampel daun Sirsak pada sampel segar dan serbuk kering. Penentuan kadar air berguna untuk menyatakan kandungan zat dalam tumbuhan sebagai persen bahan kering. .Kadar air suatu sampel erat kaitannya dengan mutu sampel dan kecepatan kerusakan sampel, baik yang sifatnya 
mikrobiologi ataupun kimia (Krismawati, 2007).

Adapun hasil kadar air sampel daun pulai segar dan serbuk daun kering, sebagaimana pada Tabel 1.

Tabel 1. Kadar air sampel

\begin{tabular}{|l|l|}
\hline \multicolumn{1}{|c|}{ Sampel } & Kadar Air $(\boldsymbol{\%} \mathbf{b} / \mathbf{b})$ \\
\hline Segar & $68,90 \%$ \\
\hline Serbuk kering & $8,34 \%$ \\
\hline
\end{tabular}

Sampel daun Pulai segar mengandung kadar air sebesar 68,90\% dan sampel serbuk daun kering mengandung kadar air sebesar 8,34\%. Sampel tersebut telah memenuhi standar aturan penyimpanan yang aman terhadap pertumbuhan jamur ataupun mikroba. Hal ini sesuai dengan pernyataan yang dikemukakan oleh Winarto (2007) bahwa sampel dikatakan baik dan dapat disimpan dalam jangka waktu yang lama apabila memiliki kadar air kurang dari $10 \%$, karena pada tingkat kadar air tersebut sampel dapat terhindar dari pertumbuhan jamur yang cepat.

\section{Ekstraksi Alkaloid Daun Pulai}

Ekstraksi merupakan pengambilan zat aktif yang semula berada dalam sel tanaman dengan menggunakan pelarut tertentu. Pada penelitian ini digunakan metode ekstraksi secara maserasi dan ekstraksi asam basa.

Penggunaan pelarut etanol $95 \%$ sebagai pelarut pengekstraksi pada proses maserasi karena menurut Harbone (1987) alkaloid dari tumbuhan bersifat basa sehingga untuk melarutkannya dapat dilakukan dengan alkohol yang bersifat asam lemah.

Hasil rendemen ekstraksi maserasi daun pulai ditunjukkan pada Tabel 2 .

Tabel 2 Hasil rendemen ekstraksi maserasi daun pulai

\begin{tabular}{|c|c|c|}
\hline $\begin{array}{c}\text { Berat sampel } \\
(\mathbf{g})\end{array}$ & $\begin{array}{c}\text { Berat } \\
\text { ekstrak }(\mathbf{g})\end{array}$ & $\begin{array}{c}\text { Rendemen } \\
(\boldsymbol{\%})(\mathbf{b} / \mathbf{b})\end{array}$ \\
\hline 100 & 22,57 & 22,57 \\
\hline
\end{tabular}

Hasil ekstrak kemudian ditimbang sebanyak 20 gr lalu di asamkan dengan $\mathrm{H}_{2} \mathrm{SO}_{4} 2 \%$. Penambahan asam bertujuan untuk menarik alkaloid dan membentuk garam alkaloid/amina serta memperbesar kelarutan alkaloid dalam air (Robinson, 1995). Adapun reaksi yang terjadi saat penambahan asam kuat yaitu :

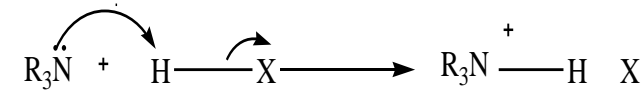

$\begin{array}{ll}\text { Gambar } 1 & \text { Reaksi Amina dengan Asam } \\ & \text { Kuat }\end{array}$

Setelah diasamkan lalu diekstraksi ditambahkan dengan dietil eter sebanyak 15 $\mathrm{mL}$ dan diulangi sebanyak $5 \mathrm{x}$. penambahan dietil eter bertujuan untuk mengambil senyawaan lemak dan lilin yang bersifat non polar. Hasil ekstraksi dengan dietil eter terbentuk dua fraksi yaitu fraksi asam (diatas) dan fraksi dietil eter (dibawah).

Hasil kedua fraksi tersebut masing2dipisahkan. Fraksi asam kemudian dibasakan dengan $\mathrm{NH}_{4} \mathrm{OH}$ (p.a) $25 \%$ hingga $\mathrm{pH}$ mencapai kisaran rentang $9-10$ hingga membentuk endapan. Fungsi penambahan basa untuk membebaskan alkaloid dari garamnya agar terbentuk basa alkaloid yang bebas.

Adapun rekasi yang terjadi saat penambahan basa yaitu :

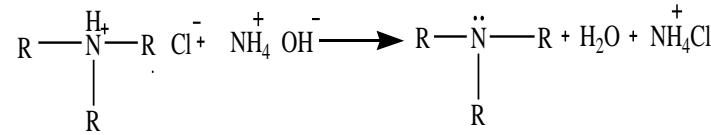

Gambar 2 Reaksi pembasaan asam Amina dengan asa lemah.

Fraksi asam yang telah dibasakan hingga pH menjadi 9-10 lalu diekstraksi dengan ditambahkan klorofom sebanyak 15 $\mathrm{mL}$. Penambahan kloroform ini berfungsi untuk menarik dan mengambil alkaloid yang sudah bebas dari garamnya, karena alkaloid bebas mudah larut dalam pelarut organik sedangkan garam alkaloid tidak larut.

Hasil penambahan kloroform ini terbentuk dua fraksi yaitu fraksi air (diatas) dan fraksi klorofom (dibawah). Fraksi 
klorofom diambil dan selanjutnya pisahkan ekstrak dengan pelarutnya dengan menggunakan rotary evaporator vacuum lalu ekstrak kental yang didapat dialiri gas $\mathrm{N}_{2}$.

Hasil rendemen ekstraksi maserasi daun pulai ditunjukkan pada Tabel 3 .

Tabel 3. Hasil rendemen ekstraksi maserasi daun pulai ditunjukkan pada

\begin{tabular}{|c|c|c|}
\hline $\begin{array}{c}\text { Warna } \\
\text { ekstrak }\end{array}$ & $\begin{array}{c}\text { Berat } \\
\text { ekstrak (g) }\end{array}$ & $\begin{array}{c}\text { Rendemen } \\
(\boldsymbol{\%})(\mathbf{b} / \mathbf{b})\end{array}$ \\
\hline $\begin{array}{c}\text { Coklat } \\
\square\end{array}$ & $0,37 \mathrm{gr}$ & $0,37 \%$ \\
\hline
\end{tabular}

\section{Uji Antitoksoplasma}

Penelitian uji antitoksoplasma in vivo ini dilakukan untuk mengetahui efek dari ekstrak kasar alkaloid dari daun Pulai dengan berbagai variasi dosis bertingkat ( 25 $\mathrm{mg} / \mathrm{kg} \mathrm{BB} ; 50 \mathrm{mg} / \mathrm{kg} \mathrm{BB} ; 75 \mathrm{mg} / \mathrm{kg} \mathrm{BB}$ ) terhadap hewan uji dengan melihat daya hidup hewan uji (mencit) terhadap pertumbuhan parasit yang menginfeksi tubuh hewan uji serta persen jumlah takizoit dalam intraperitonel hewan uji.

Adapun hasil pengamatan gambaran daya hidup mencit ditunjukan pada Tabel 4.

Terapi diberikan selama 8 hari dengan tujuan diharapkan pada hari ke- 8 sudah dapat menghambat pertumbuhan

parasit secara efektif serta memperpanjang daya hidup mencit. Efektif atau tidaknya ekstrak terhadap mencit yang terinfeksi parasit Toxoplasma gondii dilihat dari ketahanan daya hidup mencit jika dalam waktu minimal 6-7 hari mencit masih dalam keadaan hidup dapat diindikasikan bahwasannya ekstrak kasar alkaloid mampu sebagai antitoksoplasma. Dalam penelitian Subekti dkk, (2005) menyatakan bahwa infeksi dengan dosis $1 \times 10^{3}$ takizoit per mencit, terjadi perpanjangan usia hidup yang sesungguhnya yaitu terjadi pada hari ke-4 paska infeksi.
Tabel 4. Hasil pengamatan gambaran daya hidup mencit

\begin{tabular}{|l|c|c|c|c|c|c|c|c|c|c|c|}
\hline $\begin{array}{l}\text { Kelompok } \\
\text { perlakuan }\end{array}$ & \multicolumn{7}{|c|}{ Jumlah mencit yang hidup/ekor } \\
\hline Hari ke- & 0 & 1 & 2 & 3 & 4 & 5 & 6 & 7 & 8 & 9 & 10 \\
\hline $\begin{array}{l}\text { Kontrol negatif } \\
\text { + CMC-Na 1 \% }\end{array}$ & 6 & 6 & 5 & 5 & 4 & 3 & 1 & 0 & 0 & 0 & 0 \\
\hline $\begin{array}{l}\text { Kontrol positif } \\
\text { + spiramycin }\end{array}$ & 6 & 6 & 6 & 6 & 6 & 5 & 4 & 4 & 4 & 3 & 3 \\
\hline $\begin{array}{l}\text { Perlakuan dosis } \\
25 \text { mg/Kg BB }\end{array}$ & 6 & 6 & 6 & 6 & 6 & 5 & 5 & 4 & 3 & 1 & 1 \\
\hline $\begin{array}{l}\text { Perlakuan dosis } \\
50 \text { mg/Kg BB }\end{array}$ & 6 & 6 & 6 & 6 & 6 & 5 & 3 & 3 & 2 & 2 & 0 \\
\hline $\begin{array}{l}\text { Perlakuan 3 } \\
\text { dosis 75 mg/Kg } \\
\text { BB }\end{array}$ & 6 & 6 & 6 & 6 & 6 & 4 & 3 & 2 & 1 & 1 & 0 \\
\hline
\end{tabular}

Perhitungan jumlah takizoit intraperitoneal dilakukan pada hari ke-5 dimana hari ke -5 merupakan acuan kontrol sebagai perhitungan takizoit dikarenakan pada hari ke-5 kontrol negatif mencit sudah ada yang mati. Adapun hasil perhitungan takizoit Toxoplasma gondii yaitu ditunjukan pada Tabel 5.

Tabel 5 Hasil perhitungan takizoit Toxoplasma gondii

\begin{tabular}{|l|l|}
\hline Kelompok perlakuan & \multicolumn{1}{|c|}{$\begin{array}{c}\text { Rerata jumlah } \\
\text { takizoit }\end{array}$} \\
\hline $\begin{array}{l}\text { Kontrol negatif } \\
\text { CMC-Na 1\% }\end{array}$ & $957,5 \times 10^{3}$ \\
\hline Kontrol positif + Obat & $702,5 \times 10^{3}$ \\
\hline $\begin{array}{l}\text { Perlakuan dosis 25 } \\
\text { mg/Kg BB alkaloid\% }\end{array}$ & $737,5 \times 10^{3}$ \\
\hline $\begin{array}{l}\text { Perlakuan dosis 50 } \\
\text { mg/Kg BB alkaloid }\end{array}$ & $787,5 \times 10^{3}$ \\
\hline $\begin{array}{l}\text { Perlakuan dosis 75 } \\
\text { mg/Kg BB alkaloid }\end{array}$ & $817,5 \times 10^{3}$ \\
\hline
\end{tabular}

Dari data penelitian di atas membuktikan bahwa ekstrak kasar alkaloid memperpanjang usia mencit hingga hari terapi terakhir ke-8 serta menghambat reduksi pertumbuhan takizoit Toxoplasma gondii. Dari keseluruhan variasi konsentrasi dosis terapi ekstrak kasar alkaloid yang diberikan keseluruhannya memiliki potensi sebagai antitoksoplasmosis akan tetapi kenyataannya ketika konsentrasi meningkat dari $25 \mathrm{mg} / \mathrm{Kg} \mathrm{BB} \mathrm{-} 75 \mathrm{mg} / \mathrm{Kg} \mathrm{BB}$ mengalami kenaikan jumlah takizoit intraperitonealnya hal ini dapat dikatakan 
antara dosis dengan efek terhadap perkembangan takizoit dapat dikatakan tidak signifikan akan tetapi tetap berkorelasi. Ketidaksignifikan tersebut dapat disebabkan adanya jumlah parasit yang diinjeksi di awal perlakuan memiliki selisih yang sangat kecil atau memiliki perbedaan jumlah dengan injeksi tidak tepat $10^{3}$. Proses replikasi perkembangan takizoit pada setiap mencit juga memiliki perbedaan hal ini dimungkinkan pengaruh dari kondisi biologis dan fisiologis dari masing-masing mencit yang memiliki imunitas yang berbeda.

\section{Uji Alkaloid}

Hasil uji positif alkaloid ditunjukkan dengan terbentuknya endapan berwarna jingga terhadap reagen Dragendorff (kalium tetraiodobismutat) dan endapan putih terhadap reagen Mayer (kalium tetraiodomerkurat). Menurut Harbone (1987) ekstrak yang positif alkaloid akan membentuk endapan jingga dengan reagen Dragendorff dan membentuk endapan putih dengan reagen Mayer. Endapan terbentuk karena adanya pembentukan senyawa kompleks antara ion logam dari reagen dengan senyawa alkaloid. Selanjutnya tujuan penambahan $\mathrm{HCl} 2 \%$ dalam uji alkaloid adalah untuk mengekstrak alkaloid karena alkaloid bersifat basa sehingga biasanya diekstrak dengan pelarut yang mengandung asam.

Hasil analisis kualitatif golongan senyawa alkaloid yang terdapat dalam ekstrak kasar alkaloid daun Pulai ditunjukkan pada Tabel 6 .

Tabel 6 Hasil analisis kualitatif golongan senyawa alkaloid yang terdapat dalam ekstrak kasar alkaloid daun Pulai

\begin{tabular}{|l|l|l|}
\hline $\begin{array}{l}\text { Golongan } \\
\text { Senyawa }\end{array}$ & Reagen & Hasil Reaksi Warna \\
\hline \multirow{2}{*}{ Alkaloid } & Dragendorf & Endapan jingga \\
\cline { 2 - 3 } & Mayer & Endapan putih \\
\hline
\end{tabular}

Prinsip uji alkaloid pada dasarnya ialah adalah pengendapan alkaloid dengan logam-logam berat. Pereaksi Dragendorff digunakan untuk mendeteksi adanya alkaloid dikarenakan pereaksi ini mengandung bismut yang merupakan logam berat atom tinggi (Sirait, 2007). Alkaloid adalah senyawa yang tersusun dari atom nitrogen yang PEB (Pasangan Elektron Bebas) yang dapat digunakan untuk membnetuk ikatan kovalen koordinat dengan ion logam (Mc Murry, 2004 dalam Marliana, 2005).

\section{Identifikasi Senyawa Alkaloid dengan KLT}

Identifikasi senyawa alkaloid dilakukan pengamatan di bawah lampu UV dengan panjang gelombang $366 \mathrm{~nm}$. Dari 5 macam eluen yang digunakan eluen etil asetat : metanol : air (6: $4 \quad$ : 2$)$ menunjukkan hasil pemisahan paling bagus dengan menghasilkan 6 buah spot deng nilai $\mathrm{Rf}(0,08-0,76)$ dengan warna yang muncul pada pengamatan panjang gelombang $366 \mathrm{~nm}$ ialah jingga, ungu kebiruan dan coklat. seperti ditunjukkan pada Gambar 3:

Gambar 3 Hasil KLTA ekstrak kasar alkaloid dengan eluen etil asetat : metanol : air $(6: 4: 2)$.

Dugaan tersebut didukung oleh hasil penelitian yang dilakukan oleh Marliana (2007) bahwa pemisahan senyawa alkaloid dengan variasi eluen etil asetat : metanol : air $(6: 4: 2)$ dengan pereaksi penyemprot reagen Dragendorff menunjukkan adanya alkaloid jika timbul warna coklat atau jingga setelah penyemprotan dalam ekstrak. Bila tanpa pereaksi kimia, di bawah lampu UV $366 \mathrm{~nm}$, alkaloid akan berfluoresens biru, biru-hijau atau ungu (Marliana, 2007) serta Lusiana (2009), dan Aripin (2007) yang menunjukkan adanya senyawa 
alkaloid dengan spot berwarna jingga kecoklatan.

\section{KESIMPULAN DAN SARAN KESIMPULAN}

1. Ekstrak kasar alkaloid daun pulai (Alstonia scholaris L.R.Br) pada semua dosis yaitu pada dosis $25 \mathrm{mg} / \mathrm{Kg} \mathrm{BB}$; $50 \mathrm{mg} / \mathrm{Kg} \mathrm{BB}$ dan dosis $75 \mathrm{mg} / \mathrm{Kg} \mathrm{BB}$ dapat memperpanjang daya hidup mencit yang terinfeksi takizoit Toksoplasma gondii strain RH cukup baik dibandingkan pada kontrol negatif.

2. Ekstrak kasar alkaloid daun pulai (Alstonia scholaris L.R.Br) efektif mengurangi kecepatan replikasi takizoit Toxoplasma gondii strain $\mathrm{RH}$ pada hari ke-5 dengan hasil jumlah takizoit $737,5 \times 10^{3}$ pada dosis 25 $\mathrm{mg} / \mathrm{Kg} \mathrm{BB}, 787,5 \times 10^{3}$ pada dosis 50 $\mathrm{mg} / \mathrm{Kg}$ BB dan $817,5 \times 10^{3}$ pada dosis $75 \mathrm{mg} / \mathrm{Kg} \mathrm{BB}$ yang keseluruhan memberikan penghambatan yang cukup baik dibandingkan dengan kontrol negatif.

3. Eluen terbaik dalam pemisahan senyawa alkaloid dalam ekstrak kasar alkaloid yaitu etil asetat : metanol : air $(6: 4: 2)$.

\section{SARAN}

1. Perlu dilakukan identifikasi lebih lanjut untuk mengetahui dugaan struktur senyawa yang berpotensi sebagai antitoksoplasma dengan menggunakan LC-MS dan H-NMR.

2. Perlu dilakukan perhitungan jumlah takizoit intraperitoneal pada hari sebelum dan sesudah mencit dinyatakan mati keseluruhan pada kontrol negative.

\section{DAFTAR PUSTAKA}

Arifin, H.; Anggraini, N.; Dian, H. dan Rasyid, R. 2006. Standarisasi Ekstrak Etanol Daun Eugina cumini Merr. Jurnal. Jakarta: Jurusan Farmasi Fakultas MIPA Universitas Andalas.

Diah, Daru Asih.P. 2012. Potensi Ekstrak Umbi dan Daun Ubi Jalar Ungu sebagai Inhibitor $\alpha$-glukosidase. Departmen Kimia FMIPA Institut Pertanian Bogor. Skripsi diterbitkan.

Ekasari, W., Widyawaruyanti, A., Fuad, A., Hafid. 2005. Uji Antimalaria Hasil Fraksinasi Ekstrak Kloroform Daun Cassia siamea Pada Mencit Terinfeksi Plasmodium berghei. Fakultas Farmasi.

Dubey J.P dan Weiss Louis M. 2009. Toxoplasmosis: a History of Clinical Observations. Departments of Medicine (Division of Infectious Diseases) and Pathology (Division of Parasitology), AlbertEinstein College of Medicine, Animal Parasitic Diseases Laboratory, Animal and Natural Resources Institute Agricultural ResearchService, United States Department of Agriculture.

Harbone, J.B. 1987. Metode Fitokimia

Penentuan Cara Modern

Menganalisis Tumbuhan. Penerjemah

Kosasih Padmawinata dan Iwang Soediro. Bandung: Institut Teknologi Bogor.

Iskandar T, Didik T.S, dan Eka F.D. 2006. Gambaran Splenosit, Limpa dan Kekebalan pada Mencit Galur Balb/c Yang Diberi Alantoin dan Dinfeksi Toxoplasma gondii. Bogor. Seminar Nasional Teknologi Peternakan dan Veteriner.

Krismawati, Agnes. 2007. Pengaruh Ekstrak Tanaman Ceremai, Delima Putih, Jati Belanda, Kecombrang, dan Kemuning secara Invitro terhadap Proliferasi Sel Limfosit Manusia. Departmen Ilmu Teknologi Pangan Fakultas Teknologi Pertanian Institut Pertanian Bogor . Skripsi diterbitkan

Kulsum, U. dan Gusmailina. 2003.

Tanaman Obat Asal Hutan Sebagai Komoditi Hasil Hutan Bukan Kayu (HHBK) Potensial (Bagian I). Info hasil hutan. Vol.10. No.2. hal: 83-96. Bogor: Pusat Penelitian Dan Pengembangan Teknologi Hasil Hutan. 
Kumolosasi, E., Soemardji, A,. Ruslan, K,. dan Yuliani. 2004. Efek Teratogenik Ekstrak Etanol Kulit Batang Pule ( Alstonia scholaris R.Br) pada Tikus Wistar. Jurnal Matematika dan Sains Vol. 9 No. 2 Juni 2004. Departemen Farmasi FMIPA-ITB: Bandung.

Kusrini, Dewi., Muhammad Titis B.M., dan Fachriyah, 2013. Isolasi,Identifikasi dan Uji Aktifitas Senyawa Alkaloid Daun Binahong (Anredera cordifolia (Tenore) Stenis). Jurnal Chemistry Vol 1. Jurusan Kimia FSM Universitas Diponegoro. Semarang.

Lee, dkk. 2012. Alkaloids Contents, Cytotoxity and Anti-Toxoplasma gondii Activity of Psidium Guajava L. and Tinospora Crispa. Bangladesh J Pharmacol. Vol. 7: 272-276.

Lusiana, Helen. 2009. Isolasi dan Uji Anti Plasmodium secara In Vitro Senyawa Alkaloid dari Albertisia papuana BECC. Sekolah Pascasarjana Institut Pertanian Bogor. Bogor. Skripsi diterbitkan.

Marliana E. 2007. Analisis Senyawa Metabolit Sekunder Dari Batang Spatholobus ferrugineus (Zoll \& Moritzi) Benth yang Berfungsi Sebagai Antioksidan. Jurnal Penelitian MIPA, 1 (1): 23-29.

Marliana, S.D.; Suryanti, V. dan Suyono. 2005. Skrining Fitokimia dan Analisis Kromatogrfi Lapis Tipis Komponen Kimia Buah Labu Siam (Sechium edule Jacq. Swartz.) dalam Ekstrak Etanol. Surakarta: Jurusan Biologi FMIPA UNS. Jurnal Biofarmasi 3 (1): 26-31 ISSN: 1693-2242.

Mulyati. R, Sunarti. S, Diah. S, dan Suhardjono. P. 2006. Pemanfaatan Tumbuhan Obat secara Tradisional oleh Masyarakat Lokal di Pulau Wawonii, Sulawesi Tenggara. Bogor. Jurnal Biodiversitas Vol. 7 No. 3. Pusat Penelitian Biologi, LIPI, Bogor.

Ronize Andreia F, Alaide Braga de Oliveira, Simone A.G, Jose M, Ricardo T.F, Pedro Henrique and
Ricardo Wgner. 2012. New napthoquinones and alkaloid with in vitro activity against Toxoplasma gondii RH and EGS strains. Journal Experimental Parasitology. Laboratório de Microscopia, Instituto de Ciências Agrárias, Faculdade de Estudos Administrativos, FEAD, Brazil

Savitri, E.S. 2008. Rahasia Tumbuhan Berkhasiat Obat Perspektif Islam. Malang: UIN Malang Press.

Sirait, Median. 2007. Penuntun Fitokimia dalam Farmasi. Bandung: ITB.

Subekti, Didik T. 2005. efek pemberian ekstrak etanol buah mengkudu pada mencit setelah diinfeksi Toxoplasma gondii galur RH. JITV. Volume 10. No. 4. Hal: 305-314.

Subekti, D. T., dan Arrasyid, N, K. 2006. Imunopatogenesis Toxoplasma Gondii Berdasarkan Perbedaan Galur. Wartazoa. Vol.6. No. 3: 128-145.

Supriadi. 2001. Tumbuhan Obat Indonesia. Penggunaan dan Khasiatnya. Pustaka Populer Obor. 145 hal.

Susanto, L. Supali, T dan Gandahusada, S. 2002. Penentuan Konsentrasi Minimal Gen B1 dan Gen P30 Toxoplasma gondii Yang Masih Terdeteksi Dengan Reaksi Polimerase Jurnal Kesehatan Vol. 6 Bagian Parasitologi, Fakultas Kedokteran Universitas Indonesia.

Teguh,Wahju.S. Supranowo, dan Akhmad Fariz N.2008. Pengaruh Peningkatan Dosis dan Lama Infeksi Toxoplasma gondii Galur RH terhadap Perubahan Patologis Jaringan Otot Bergaris Menct (Mus musculus) Galur Balb/C. Jurnal Department Veteriner Fakultas Kedokteran Hewan Universitas Brawijaya. 